https://doi.org/10.52240/1857-2367.2020.2(21).23

\title{
POTENTIAL SITES FOR RESTORATION OF CRAMBE TATARIA SEBEÓK (BRASSICACEAE) POPULATIONS IN THE REPUBLIC OF MOLDOVA
}

\author{
Tatiana IZVERSCAIA, Veaceslav GHENDOV \\ “Al. Ciubotaru” National Botanical Garden (Institute), \\ Chisinau, Republic of Moldova
}

\begin{abstract}
Four most promising steppe sectors for population recovery, restoration and conservation of threatened with extinction rare Crambe tataria Sebeók species were studied:" Cîzlar", "Slobozia MareVăleni", "Cioc-Maidan" and "Sîngerei".
\end{abstract}

Key words: Crambe tataria Sebeók, flora, Republic of Moldova

Whilst fulfilling the research program of the laboratory of Natural flora and Herbarium of the National Botanical Garden (Institute) on repopulation programs in natural habitats of threatened with extinction species of Community interest and included in international conventions, a rare species in the Republic of Moldova was chosen as one of the objects for study, reproduction and repatriation to nature Crambe tataria Sebeók (Brassicaceae).

In the region, this species is protected by the state (category II - endangered), included in the $3^{\text {rd }}$ edition of the Red Data Book of the Republic of Moldova as a threatened species (category EN) [1]. Internationally protected by the Berne Convention [2] and included in Appendices II and IV of the Habitats Directive [3]. The species is also rare on the territory of Ukraine, where it is included in the Red Book as a vulnerable species.

Crambe tataria is a typical steppe species with a PonticPannonian-Sarmatian disjointed range of distribution. In the Republic of Moldova it occurs sporadically, except in the north-eastern and southern parts. It grows as part of the grasslands of anthropogenic variants of primary steppes, steppe and limestone slopes, glades and edges of the Quercus pubescens Willd. forest stands. In order to make available exsitu collection of Crambe tataria and possible for population recovery and restoration programme into natural habitats, during 2020 numerous areas with steppe vegetation were examined, among which we chose 4 the most promising for the conservation: "Cîzlar" (Figure 1), "Slobozia Mare-

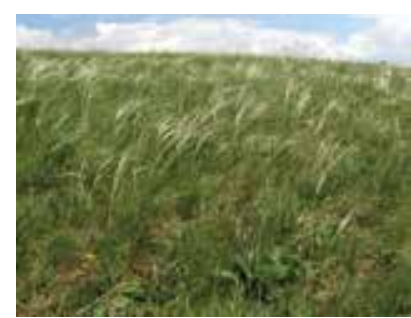

Figure 1. Sector "Cîzlar"

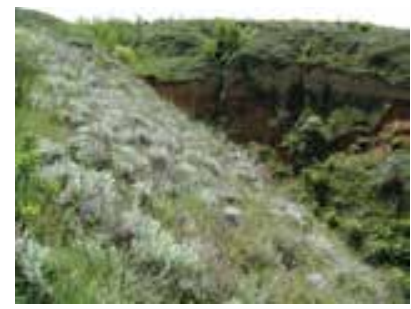

Figure 2. Sector "Slobozia Mare-Văleni"

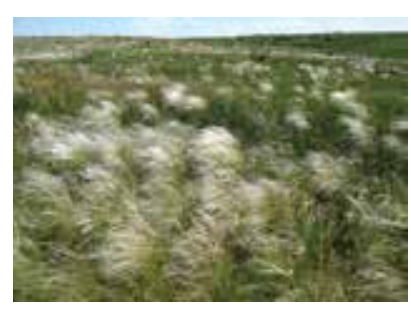

Figure 3. Sector "CiocMaidan" Văleni" (Figure 2), "Cioc-Maidan" (Figure 3) and "Sîngerei” (Figure 4).

The "Cîzlar» sector is located in the southern part of the Cîzlar village, Leova district. Fragments of anthropogenic variants of the primary steppes have been preserved 


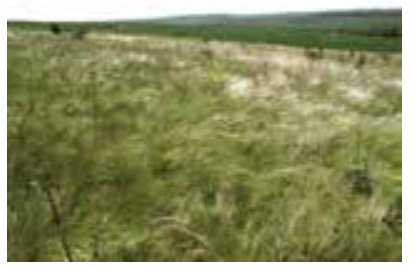

Figure 4. Sector "Sîngerei"

here: Stipetum (capillata, lessingiana) crinitariosum (villosa), Festuceta (valesiaca) herbosa, Stipeto (ucrainica) - festuceta (valesiaca) herbosa, Festuceto (valesiaca) stipeta (ucrainica) herbosa. This site recently was proposed to be taken under the state protection.

The «Slobozia Mare-Văleni» site is located in the buffer zone of the Prutul de Jos nature reserve between the Slobozia Mare and Văleni communes, Cahul district. Following steppe communities have survived here: Stipetum (ucrainica) herbosum, Festucetum (valesiaca) - stipeto (ucrainica) herbosum, Festucetum (valesiaca) - stipeto (ucrainica+lessingiana+cap illata) herbosum, Festucetum (valesiaca) - ephedroso herbosum, Allietum (guttatum) herbosum.

The "Cioc-Maidan" site is located at $5 \mathrm{~km}$ east of commune Cioc-Maidan (UTA Găgăuzia). The steppe communities of Stipetum (lessingiana) herbosum have been preserved here.

The "Sîngerei" site is a typical area of steppe vegetation. Located at 3,5 km southwest of town Singerei. The following steppe communities have survived here: Stipeto (pulcherrima, pennata) - festucetum (valesiaca) caraganosum (frutex), Festuceto (valesiaca) - stipeta (pulcherrima) herbosa, Stipeto (tirsa) - festuceta (valesiaca) herbosa, Stipeto (pennata) - festuceta (valesiaca) herbosa.

Acknowledgments. The research was supported by the NARD through the project "Research and conservation of vascular flora and macromycobiota of the Republic of Moldova”, 20.80009.7007.22 (contract Nr. 71/PS/2020).

\section{BIBLIOGRAPHY}

1. Cartea Roşie a Republicii Moldova. Ed. III. Chișinău: "Știința", 2015. 492 p.

2. Convention on the Conservation of European Wildlife and Natural Habitats. Bern, Switzerland. 1979.

3. Council Directive 92/43/EEC of 21 May 1992 on the conservation of natural habitats and of wild fauna and flora, O.J. L206, 22.07.92.1992. P. 0007-0050. 